\title{
SPATIAL INVENTORY OF ARCHAEOLOGICAL RESOURCES IN DOBROGEA USING GIS IN ORDER TO QUANTIFY THE HISTORICAL TOURIST POTENTIAL
}

DOI: https://doi.org/10.18509/GBP210539d

UDC: 904:338.48]:[528.4.067:004(498)

\author{
Vasile-Gabriel Dascălu ${ }^{1,2}$ \\ Andra Birică ${ }^{1,2}$ \\ Joiță Oana Elena ${ }^{1,2}$ \\ Burlui Cornel Alexandru, ${ }^{1,2}$ \\ Drăghici Cristian Constantin ${ }^{1,2}$ \\ ${ }^{1}$ Research Center for Integrated Analysis and Territorial Management, University of Bucharest, \\ 4-12 Regina Elisabeta Avenue, 030018 Bucharest, Romania \\ ${ }^{2}$ Faculty of Geography, University of Bucharest, 1, Nicolae Bălcescu Blvd, 010041 Bucharest, \\ Romania
}

\begin{abstract}
Dobrogea is a historical region of Romania that includes a great diversity of archaeological resources, imposing a spatial inventory in a different way from the current ones. This study proposes the use of GIS technology in terms of organization and structuring of archaeological resources made available by the National Archaeological Record of Romania. The integration of data in online mapping applications can help to create a stronger link between the tourist and the tourist location, which has positive implications for the regional economic development. The results of the study consist in a spatial database of the fortresses, Roman camps and other archaeological resources from Dobrogea having as main role the exposure of the historical tourist potential of the study area. The information obtained will contribute to future studies for the implementation of digital methods to increase the tourist attractiveness of these archaeological resources.
\end{abstract}

Keywords: Tourism, Dobrogea, archaeology, GIS, inventory

\section{INTRODUCTION}

Although Geographic Information Systems (GIS) began to be used in archeology after 1990, mapping has always been one of the main practices in the analysis of archaeological sites[1]. GIS is mainly used in the collection of archaeological data and less for the transmission of information and tourism promotion, even if the potential of this technology is very high[2].

This paper presents the inventory of archaeological data set from the historical region of Dobrogea, Romania. The elements of the archaeological hertiage will receive spatial references which will help to create interactive maps. Thus, we want to use technology to develop the cultural tourism of the analyzed region. For this, mapping of the archaeological resources is an important step.

Dobrogea is a region with a very diverse history due to the many nationalities that have lived here over the millennia. Greek settlers built here over 2500 years ago the first cities on the current territory of Romania[3] and in the year 46 B.C.E. Dobrogea became a territory of the Roman Empire being the first region of Romania that was annexed to Rome[4]. Many settlements and fortresses were built in the next historical periods: 
Dacian-Getic, Greek, Roman, Byzantine and Medieval. This aspect highlights a very rich archaeological fund which creates opportunities for the development of tourism and also for the regional economy.

The best known project for mapping archaeological resources at the national level, not only in Dobrogea was coordinated by Bogdan Șandric and is called Cartographic server for the National Cultural Heritage[5]. This project presents a wide set of scientific information, being a very good source of data for researchers. Through this study, we aim to extract information about archaeological sites which have a high tourist potential and to create a spatial database for interactive maps applications made especially for tourists.

\section{MATERIALS AND METHODS}

In order to make an inventory as accurate as possible in relation to the proposed objectives, it is necessary to select those archaeological elements that can be a tourist attraction (fig. 1.), a parameter greatly influenced by their state of conservation. Archaeological discoveries and research for the Dobrogea region are objectively presented in the archive of National Archaeological Record of Romania (RAN), supported by Ministry of Culture[6].

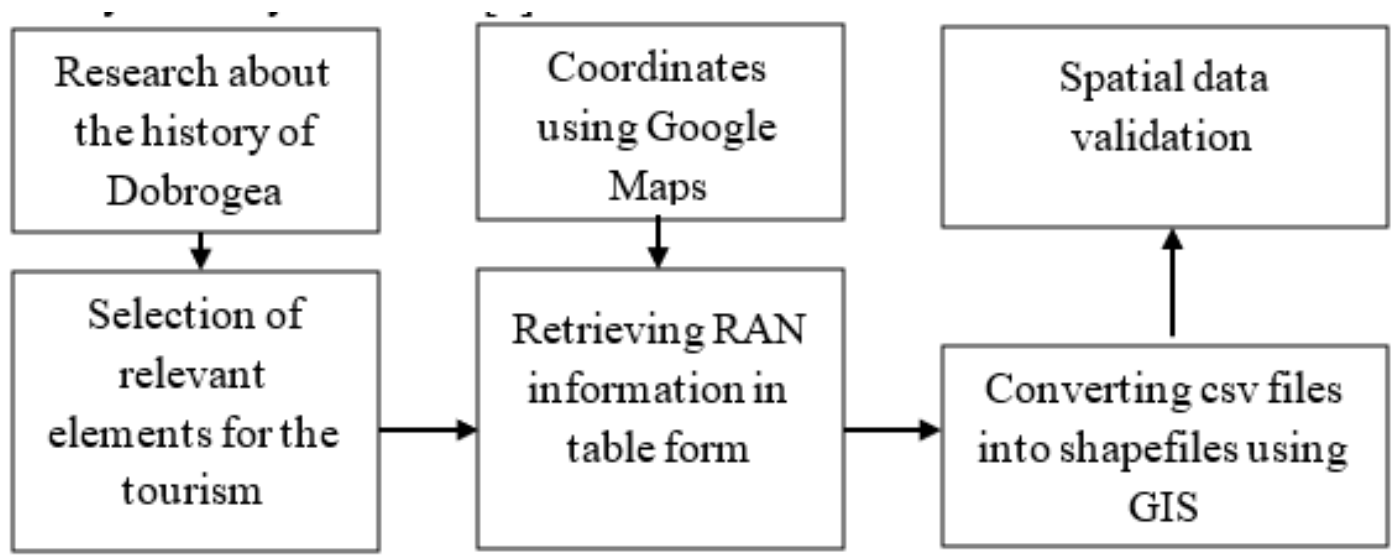

Figure 1. Scheme of work steps for obtaining the desired spatial data

The description of the archaeological resources includes information about the city/village where it is located, the county, the year of discovery, the historical period, the occupied surface and the geographical coordinates in WGS '84 projection obtained using Google Maps (fig. 1). We also created a classification based primarily on the historical period, which will help us to create interactive methods for rendering historical information from Dobrogea to increase the attractiveness of web GIS applications.

The initial data taken from different sources will be grouped in tables using Microsoft Excel, two columns being intended for geographical location (latitude and longitude). By transforming the tables into CSV files, the information will be spatialized in the opensource software QuantumGIS 3.12, based on the two columns where it's stored information about latitude and longitude (fig. 2).

Statistical and economic data are taken from the online portal of the National Institute of Statistics, Tempo Online. These can be downloaded as tables in XLSX or CSV files and then inserted into GIS[7]. 


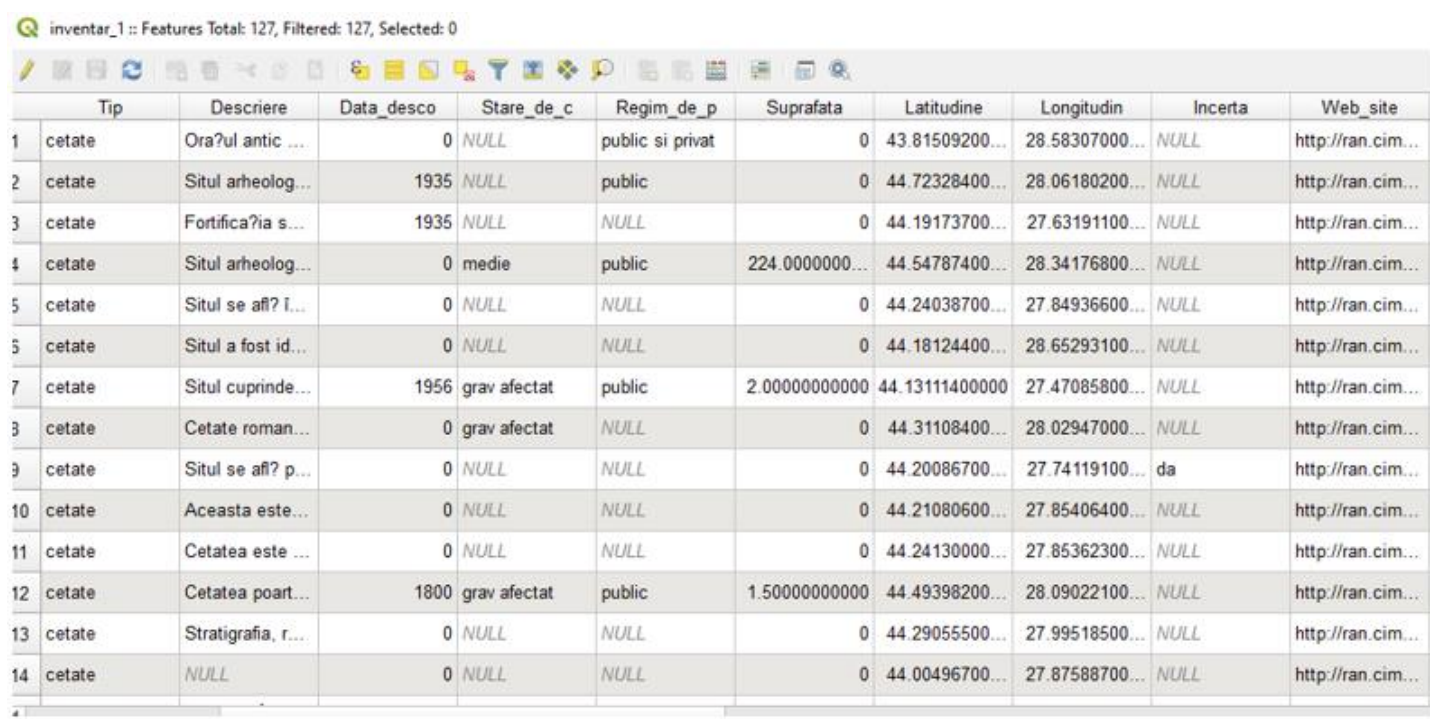

Figure 2. Part of the database entered in the QuantumGIS software

\section{RESULTS}

The database created includes 127 elements of the archaeological heritage of Dobrogea. Each incorporates information about the name of the archaeological site, the code for the list of historical monuments (where applicable), the RAN code, the year of discovery of the site, the historical period, the state of conservation, but also the geographical coordinates (table 1). Based on these spatial references, we obtained a vector point layer.

Table 1 Some of the archeological sites that have been inventoried

\begin{tabular}{|c|c|c|c|c|c|c|c|c|c|}
\hline $\begin{array}{l}\text { Archaeological } \\
\text { sites }\end{array}$ & County & $\begin{array}{l}\text { City/Villag } \\
\mathrm{e}\end{array}$ & Category & $\begin{array}{l}\text { State of } \\
\text { Consevatio } \\
\text { n }\end{array}$ & $\begin{array}{l}\text { Historica } \\
\text { l } \\
\text { Period }\end{array}$ & $\begin{array}{l}\text { Are } \\
\text { a } \\
\text { (ha) }\end{array}$ & $\begin{array}{l}\text { Propert } \\
\text { y } \\
\text { type }\end{array}$ & Latitude & $\begin{array}{l}\text { Longitud } \\
\mathrm{e}\end{array}$ \\
\hline $\begin{array}{l}\text { Antiq city of } \\
\text { Callatis }\end{array}$ & $\begin{array}{l}\text { Constanț } \\
\text { a }\end{array}$ & Mangalia & $\begin{array}{l}\text { Fortification } \\
\text { fortress }\end{array}$ & 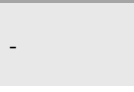 & $\begin{array}{l}\text { Greek, } \\
\text { Roman }\end{array}$ & - & $\begin{array}{l}\text { public \& } \\
\text { private }\end{array}$ & $\begin{array}{l}43.81509 \\
2\end{array}$ & 28.58307 \\
\hline Histria & $\begin{array}{l}\text { Constanț } \\
\text { a }\end{array}$ & Istria & Settlement & good & $\begin{array}{l}\text { Greek, } \\
\text { Dacian, } \\
\text { Roman }\end{array}$ & - & public & $\begin{array}{l}44.54679 \\
8\end{array}$ & 28.773503 \\
\hline Carsium & $\begin{array}{l}\text { Constanț } \\
\text { a }\end{array}$ & Hârșova & Settlement & medium & $\begin{array}{l}\text { Dacian, } \\
\text { Roman, } \\
\text { Medieval }\end{array}$ & - & public & $\begin{array}{l}44.68170 \\
6\end{array}$ & 27.951732 \\
\hline Aegyssus & Tulcea & Tulcea & $\begin{array}{l}\text { Settlement, } \\
\text { fortress }\end{array}$ & bad & $\begin{array}{l}\text { Dacian, } \\
\text { Roman, } \\
\text { Medieval }\end{array}$ & 54 & $\begin{array}{l}\text { public \& } \\
\text { private }\end{array}$ & $\begin{array}{l}45.27109 \\
5\end{array}$ & 28.490863 \\
\hline Hamlyris & Tulcea & Murighiol & $\begin{array}{l}\text { Settlement, } \\
\text { fortress }\end{array}$ & good & $\begin{array}{l}\text { Greek, } \\
\text { Dacian, } \\
\text { Roman }\end{array}$ & 3 & public & $\begin{array}{l}45.02492 \\
9\end{array}$ & 29.197761 \\
\hline $\begin{array}{l}\text { Argamum/Orgam } \\
\text { e }\end{array}$ & Tulcea & Jurilovca & $\begin{array}{l}\text { Settlement, } \\
\text { fortress }\end{array}$ & medium & $\begin{array}{l}\text { Greek, } \\
\text { Dacian, } \\
\text { Roman, } \\
\text { Medieval }\end{array}$ & 120 & public & $\begin{array}{l}44.85422 \\
2\end{array}$ & 28.590694 \\
\hline Capidava & $\begin{array}{l}\text { Constant } \\
\text { a }\end{array}$ & Capidava & $\begin{array}{l}\text { Settlement, } \\
\text { fortress }\end{array}$ & bad & $\begin{array}{l}\text { Dacian, } \\
\text { Roman, } \\
\text { Medieval }\end{array}$ & 1.5 & public & $\begin{array}{l}44.49398 \\
2\end{array}$ & 28.090221 \\
\hline
\end{tabular}

The most numerous, but also the best preserved historical vestiges in Dobrogea are located near the Danube river, on the shores of the Black Sea, and near the Lagoon Complex Razim-Sinoe. The higher popularity of the cities in the eastern part of the region lies in the high flow of tourists from the Black Sea coast (fig. 3).

Also, the spatial analysis indicates a weak development of the tourist infrastructure in areas with high density of archaeological elements (center and north of Tulcea county, west of Constanța county). The tourist accommodation establishments are grouped in the eastern part of the region, where the largest number of tourists is registered. In addition, 
many historical sites are degraded by agricultural activities, demolition, animal action, and museums exist only in a few ancient cities. Analyzing the aerial images, but also through field observations, it is evident the more and more accentuated degradation of the ancient ruins. The tourist potential is obvious where several historical vestiges are grouped in a small space, but the analysis of the tourist infrastructure shows us an important barrier in capitalizing on this potential for economic development.

Archeology is a field where Geographic Information Systems have applicability and can help capitalize on the tourist potential. By using geospatial technology we can find ways to promote tourist elements less known to tourists. Spatial data provide an overview of the analyzed element and can generate solutions to solve social, economic, historical problems, in this case.

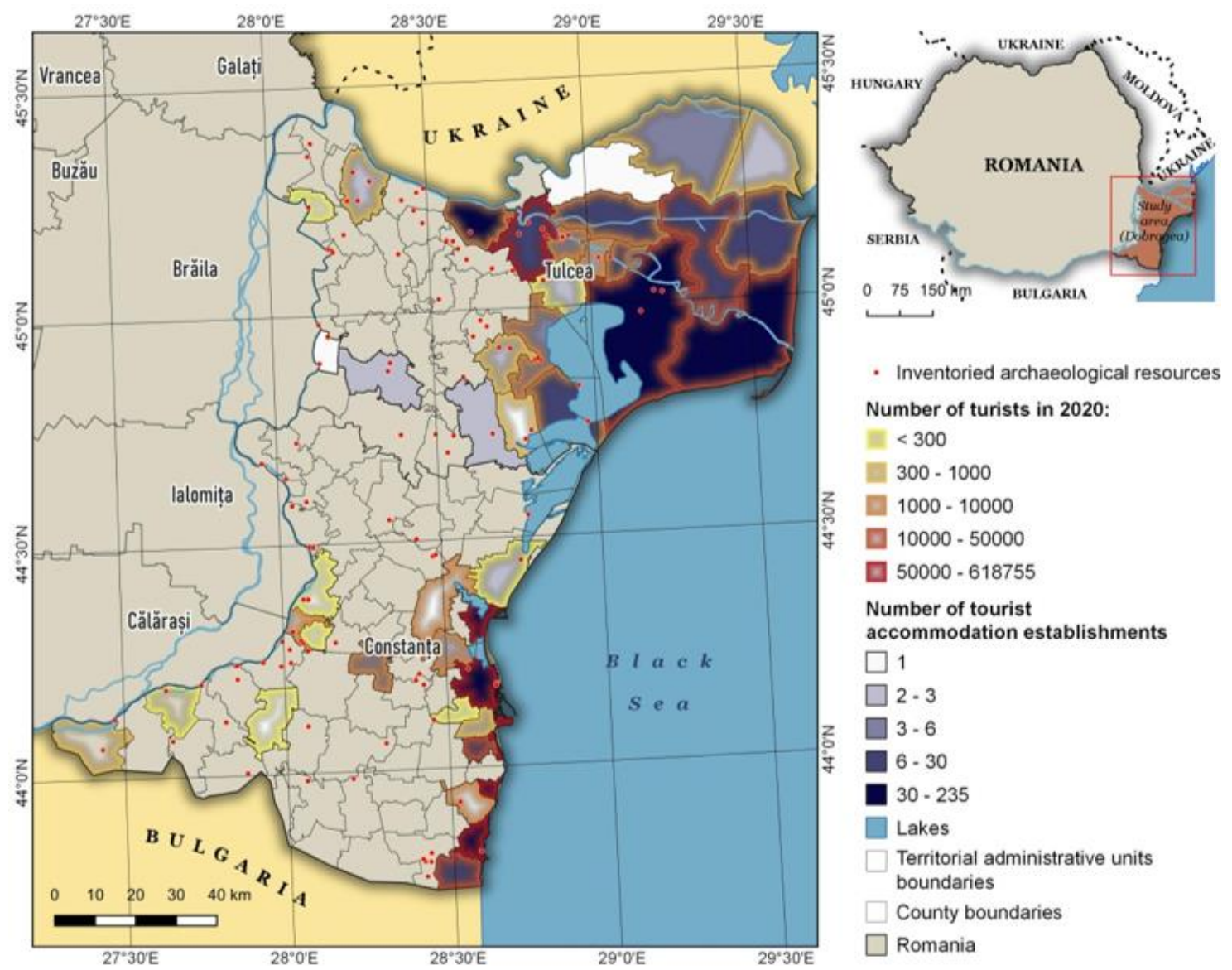

Figure 3. The correlation between the spatialized archeological heritage[6] and the tourist infrastructure from Dobrogea[7]

\section{CONCLUSIONS AND DISCUSSION}

Through this study we managed to inventory the archaeological resources in Dobrogea in a cartographic way to create the database necessary for future GIS and web GIS projects for the development of tourism in Dobrogea. GIS includes a set of tools with applicability in many fields, including tourism and archeology. Adding spatial information to historical relics helps us to understand population dynamics or factors involved in the spread of peoples in different historical periods, but also gives us insights into future geography studies on this historical subject. The advantage of using spatial information is the ease with which data can be manipulated and processed so that deeper conclusions can be 
drawn. Another advantge is the fact that spatial database can be updated easily. The methodological approach presented in this study compared to those in neighboring countries or regions aims to create a database that allows easy construction of interactive maps. For this, we have introduced a wide range of information for each archaeological objective identified in order to make the most accurate classifications in order to be able to make easy classifications of these cultural vestiges [8][9][10]. GIS techniques can be a very useful way to make the most of existing tourist resources in an area, and together with other management measures can maximize the economic resources of tourism resources[11][12].

\section{Acknowledgement:}

The authors are grateful to all the archaeologists who contributed to the discovery and analysis of the archaeological remains in Dobrogea. We would also like to thank the members and colleagues of the Research Center for Integrated Analysis and Territorial Management (CAIMT) for their support.

\section{REFERENCES}

[1] Alanna L. Warner-Smith. Mapping the GIS Landscape: Introducing "Beyond (within, through) the Grid, International Journal of Historical Archaeology, USA, vol. 24, pp. 767-779, 2020.

[2] Matthew D. Howland, Brady Liss, Thomas E. Levy \& Mohammad Najjar. Integrating Digital Datasets into Public Engagement through ArcGIS StoryMaps, Advances in Archaeological Practice, USA, vol. 8, pp. 351-360, 2020.

[3] Ioan-Aurel Pop. Scurta istorie a românilor. Editura Litera, Romania, pp.76, 2020.

[4] Ovidiu Țentea, Ioan Carol Opriş, Florian Matei-Popescu, Alexandru Rațiu \& Vlad Călina. Roman frontier in Dobrudja. A review and an update, Journal of the National Museum of Romanian History, Romania, vol. 28, pp. 9-82, 2019.

[5] National Heritage Institute [Online], Avaible at: http://www.cimec.ro/Contact.html, 2021.

[6] National Archaeological Record of Romania (RAN) [Online], Avaible at: http://ran.cimec.ro/sel.asp?Lang=EN, 2021.

[7] National Institute of Statistics. Tempo INSSE [online], Avaible at: http://statistici.insse.ro:8077/tempo-online, Romania, 2021.

[8] Marko Rukavina and Mladen Obad Šæitaroci, "Archaeological Heritage Management Process Associated with Urban and Physical Planning", Prostor, vol.23, no. 1 (49), pp. 100-117, 2015. [Online]. Available: https://hrcak.srce.hr/140958. [Accessed: 21 January 2021].

[9] Laura Comănescu, Alexandru Nedelea and Robert Dobre, The inventory of geosites from protected areas from the hydrographic basin Casimcea (Romania) : a premise for local development. Collection EDYTEM. Cahiers de géographie, 15, pp. 73-78, 2013.

[10] Keith Challis, Ziga Kokalj, Mark Kincey, Derek Moscrop and Andy J. Howard, Airborne lidar and historic environment records, Antiquity, 82, vol. 82, pp. 1055-1064, 2008.

[11] Radu-Daniel Pintilii, Daniel Peptenatu, Cristian Drăghici, Saghin Irina, Daniela-Rodica Stoian. Structural Changes in The Entrepreneurial Profile of The Creative Industries in Romania, 2nd Global Conference on Business, Economics, Management and Tourism, Czechia, vol. 23, pp. 1147-1151, 2015.

[12] Cristian-Constantin Drăghici, Radu-Daniel Pintilii, Daniel Peptenatu, Laura Georgiana Comănescu, Igor Sirodoev. The Role of SPA Tourism in the Development of Local Economies from Romania, 2nd Global Conference on Business, Economics, Management and Tourism, Czechia, vol. 23, pp. 1573-1577, 2015 